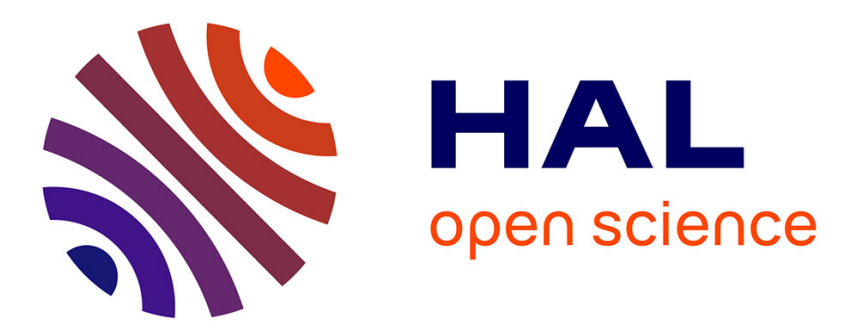

\title{
Correlation of ozone loss with the presence of volcanic aerosols
}

\author{
Thomas J. Mcgee, Paul Newman, Michael Gross, Upendra Singh, Sophie
}

Godin, Anne-Marie Lacoste, Gérard Mégie

\section{- To cite this version:}

Thomas J. Mcgee, Paul Newman, Michael Gross, Upendra Singh, Sophie Godin, et al.. Correlation of ozone loss with the presence of volcanic aerosols. Geophysical Research Letters, 1994, 21 (25), pp.2801-2804. 10.1029/94GL02350 . insu-03040903

\section{HAL Id: insu-03040903 https://hal-insu.archives-ouvertes.fr/insu-03040903}

Submitted on 3 Feb 2021

HAL is a multi-disciplinary open access archive for the deposit and dissemination of scientific research documents, whether they are published or not. The documents may come from teaching and research institutions in France or abroad, or from public or private research centers.
L'archive ouverte pluridisciplinaire HAL, est destinée au dépôt et à la diffusion de documents scientifiques de niveau recherche, publiés ou non, émanant des établissements d'enseignement et de recherche français ou étrangers, des laboratoires publics ou privés. 


\title{
Correlation of ozone loss with the presence of volcanic aerosols
}

\author{
Thomas J. McGee, ${ }^{1}$ Paul Newman, ${ }^{1}$ Michael Gross, ${ }^{2}$ Upendra Singh, ${ }^{2}$ Sophie \\ Godin, ${ }^{3}$ Anne-Marie Lacoste, ${ }^{3}$ and Gerard Megie ${ }^{3}$
}

\begin{abstract}
Statistically significant reductions of ozone compared to a climatological profile have been measured above the Observatoire de Haute Provence (OHP) in Southern France $\left(43.9^{\circ} \mathrm{N}, 5.7^{\circ} \mathrm{E}\right)$ during the months of July and August, 1992. Lidar profiles of ozone, temperature and aerosols were recorded on 25 separate nights during that time. The change in the ozone profile is correlated with the presence of volcanic aerosols from the eruption of Mt. Pinatubo. The total ozone loss amounts to approximately a $10 \%$ reduction in the total ozone column over OHP.
\end{abstract}

\section{Introduction}

Recent papers (Gleason et al., 1993; Chandra, 1993; Schoeberl et al., 1993) have focussed on the larger than expected global decrease in ozone in 1992. Using data from the TOMS instrument aboard Nimbus 7, Gleason et al. report that average global total ozone is 2 to 3 percent lower than any previous year. The mechanism of the ozone loss is as yet unknown, but is generally thought to be a result of the large influx of stratospheric aerosol from the eruption of $\mathrm{Mt}$. Pinatubo in June, 1991. One of the regions of largest decrease was the northern mid-latitudes, between $10^{\circ} \mathrm{N}$ and $60^{\circ} \mathrm{N}$, with the majority of the decrease occurring during the last nine months of 1992. The Goddard Space Flight Center's (GSFC) Stratospheric Ozone Lidar was deployed at the Observatoire de Haute Provence, France $\left(43.9^{\circ} \mathrm{N}, 5.7^{\circ} \mathrm{E}\right)$ for nearly two months during this time. Ozone profiles were recorded on 25 nights during July and August, 1992. Our results corroborate the change noted by the satellite data, correlate the change with the Pinatubo aerosol layer, and show the vertical profile of the change.

\section{The GSFC Stratospheric Ozone Lidar}

The GSFC Lidar has been described in detail before (McGee et al., 1991). Subsequent modifications added the capability of collecting Raman scattered signals from atmospheric $\mathbf{N}_{2}$. This allowed the instrument to make measurements of ozone in the presence of heavy loadings of volcanic aerosols(McGee et al., 1993). Prior to making these improvements to the system, the presence of aerosols from the

\footnotetext{
1 Laboratory for Atmospheres, NASA/Goddard Space Flight Center, Greenbelt, Maryland

2 Hughes STX Corp., Lanham, Maryland

${ }^{3}$ Service d'Aeronomie du CNRS, Paris, France
}

Copyright 1994 by the American Geophysical Union.

Paper number 94GL02350

0094-8534/94/94GL-02350\$03.00 eruption of Mt. Pinatubo had made it impossible for the lidar to retrieve an ozone profile below $30-32 \mathrm{~km}$, because of interference from aerosol scattering. Because the Raman scattered signal is dependent only on scattering from $\mathbf{N}_{2}$, there is no scattering component due to aerosols. Extinction due to aerosols must be considered in the Raman data, however, it has significantly less effect on the return signal than the scattering component. This extinction can be calculated directly from the lidar data and available meteorological data.

Equally important for the present work are the aerosol parameters which can also be extracted from the combination of Raman and elastically scattered signals. The elastically scattered signal consists of both Rayleigh (molecular) scattering, and Mie (aerosol) scattering, while the Raman signal is directly proportional to pure molecular scattering. Thus, a ratio of the two signals, normalized at a point where only molecular scattering is present, results in a vertical profile of the Aerosol Backscattering Ratio:

$$
\text { ABR- } \frac{\text { RayleightMie }}{\text { Rayleigh }}
$$

which is a measure of the concentration of aerosols. Extinction and backscatter coefficients (similar to absorption coefficients) can also be determined from the available data (Ansmann et al., 1992). The ratio of extinction to backscatter is related to the aerosol particle size distribution (Ansmann, et al., 1993), with a larger ratio indicating a smaller mean aerosol radius. The GSFC lidar provides vertical profiles of ozone, temperature, aerosol backscatter ratio, and extinction to backscatter ratio for each night that data is collected.

The ozone measurement is made using a two-color Differential Absorption (DIAL) technique. A $\mathrm{XeCl}$ laser generates $308 \mathrm{~nm}$ radiation, which is strongly absorbed by $\mathrm{O}_{3}$. The reference wavelength, which is not appreciably absorbed by $\mathrm{O}_{3}$, is the output of a XeF laser at $351 \mathrm{~nm}$. It is the difference in the slopes of these two backscattered returns, which provides for the retrieval of an ozone profile. Similarly, the Raman scattered signals at $332 \mathrm{~nm}$ and $382 \mathrm{~nm}$ can also be used to extract ozone. In this case the ozone absorption is contained in the $332 \mathrm{~nm}$ return. The laser pulses are synchronized to be transmitted about $5 \mathrm{msec}$ apart to avoid the problem of "leakage" of $351 \mathrm{~nm}$ radiation into the $332 \mathrm{~nm}$ channel. On average, for the OHP campaign, the final lidar profile is a composite of ozone derived from the Raman returns between 12 and approximately $28 \mathrm{~km}$, and from the elastic returns above $28 \mathrm{~km}$. Aerosol parameters used in this work are extracted from a combination of the $382 \mathrm{~nm}$ and 351 nm returns.

The lidar instrument deployed to OHP was different from the system which operated at Table Mountain, in February, 1992 (McGee et al., 1993) in two ways. At Table Mountain, a single mechanical chopper was used to block lidar returns for all detectors. This shutter began to open when the transmitted beams reached an altitude of $15 \mathrm{~km}$, and was 
completely open by $19 \mathrm{~km}$. There was no observable effect due to signal-induced noise (SIN) (McGee et al., 1991), therefore the photomultiplier tubes were not electronically gated. Also at TMO, no low altitude (below about $25 \mathrm{~km}$ ) elastic return was collected. At OHP two channels were added for the collection of Rayleigh backscattered returns below $25 \mathrm{~km}$, and two mechanical choppers were used, one for each of the most sensitive Rayleigh channels. The low sensitivity channels and the Raman channels were not chopped. Again, no electronic gating was used on the unchopped channels because the signal levels are 100 to 1000 times weaker than the high sensitivity Rayleigh channel. The detectors for the high sensitivity Rayleigh channels and for the Raman channels were the same at OHP as they were at TMO. Thus the validation from that campaign is still valid for the data presented herein. Subsequent analysis showed, however, that even in the Raman channel, which is three orders of magnitude down from the Rayleigh channel, there was some evidence of signal-induced-noise. This was corrected during the month of August, 1992, by electronically gating the photomultiplier tubes. Subsequent measurements showed no effect of the SIN, however total ozone measurements made before the tubes were gated are an estimated 3-5\% lower than actual. This bias is discussed further below. We should also point out, that the total ozone derived from the July balloon flights, agrees very well with total ozone from the lidar data, both on average and individual flights and profiles.

The first of the 25 profiles measured by the GSFC lidar was recorded on July 13, 1992 and the last on August 17, 1992. Five ECC (electrochemical cell) balloon sondes were flown from the observatory during the month of July. Balloon-borne ozone sondes have been flown regularly at OHP for 6 years, providing a useful climatology against which to compare the lidar data. Prior to the eruption of $\mathrm{Mt}$. Pinatubo, Brewer-Mast sondes were flown from OHP, and these were used to construct the balloon climatological profile. It is estimated, that, during the July timeframe, there is less than a $5 \%$ difference between the two types of sondes. The ozonesondes are normalized to the local Dobson values.

\section{Results}

Figure 1a is a plot of the average of the five balloon sondes flown from OHP during the time of the GSFC deployment and the lidar data from the same days. The balloons were generally flown at night to minimize time differences between the balloon and lidar measurements. Figure $1 b$ is a difference plot of the same average data, which indicates good agreement between the sondes and the lidar. Figure 1b indicates that, although there is a region near $15 \mathrm{~km}$, where there is a roughly $20 \%$ difference, there is no obvious bias. This difference is well within the standard deviation of the averages, and because of the absolute concentration of ozone at this altitude, impacts very little on the total ozone reduction.

Using all the lidar data collected during the month of July (16 separate profiles) and the five ozone sondes flown at OHP during July, 1992, we constructed a combined, average vertical profile using the sonde data from the ground up to 16 $\mathrm{km}$, and the lidar data above $16 \mathrm{~km}$. There are two sources of climatological ozone data available at OHP. Balloon sondes have been flown there since 1985 and the OHP lidar has made measurements of ozone there on a regular basis over the same time frame. Prior to the eruption of Mt. Pinatubo, in June,

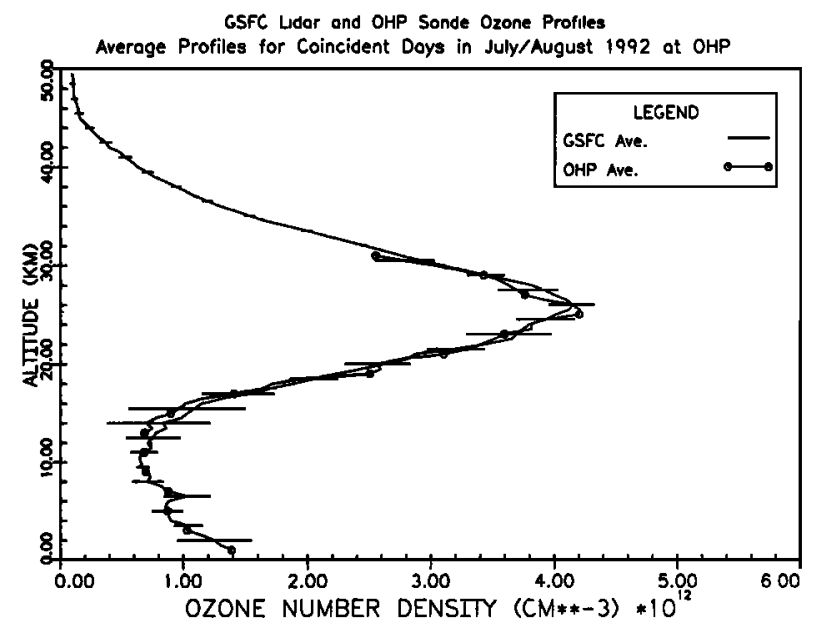

Figure 1a. A comparison of the lidar and ECC balloon sondes at OHP during the month of July, 1992. The average of five balloon sondes and of the five lidar profiles from the same days are shown in the figure. Note that the symbols are only to delineate the profiles; there are many more data points than symbols. Error bars are tied to data points, not symbols.

Ozone Difference Comporison

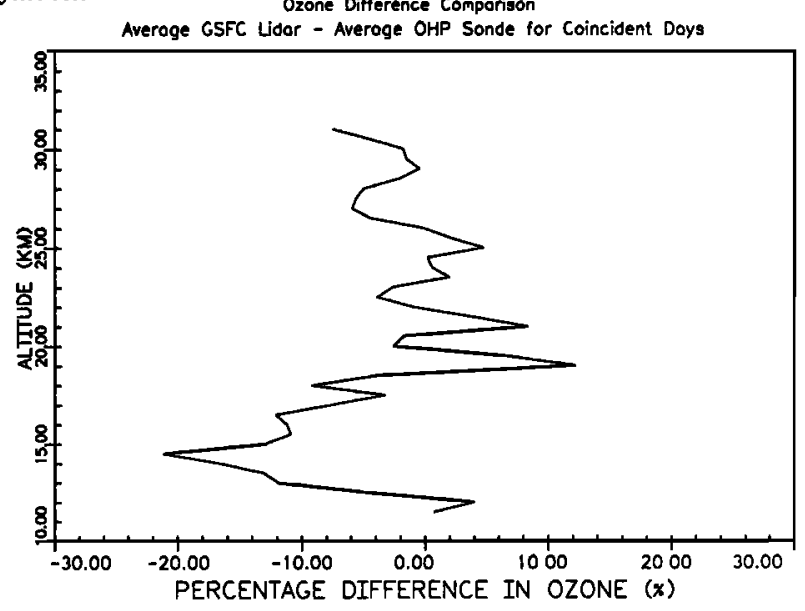

Figure 1b. A difference plot of the data in 1a.

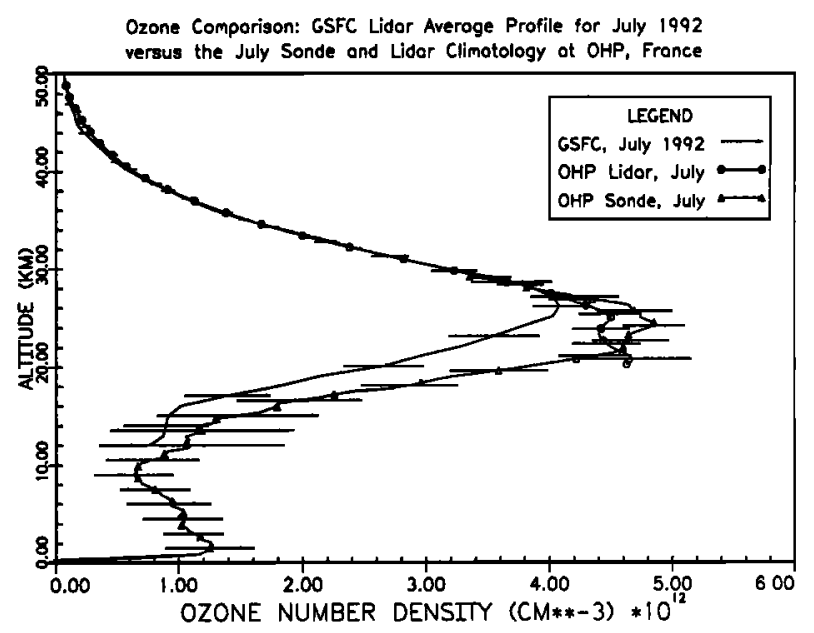

Figure 2. A comparison of the average of all the GSFC lidar data obtained in July "92 with climatological ozone profiles from both balloon sondes and from OHP lidar measurements. These climatological profiles were made up of profiles measured during July in the years prior to the eruption of Mt. Pinatubo (1985 - 1990). There were ten sondes flown which are included in the balloon profile, and 39 profiles in the OHP lidar profile. 


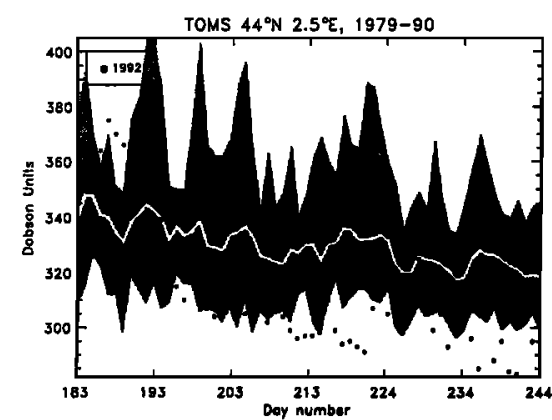

Figure 3. A plot of the Nimbus 7 TOMS total column ozone data taken over OHP between 1979 and 1990, from July 1 to August 31. The solid line indicates the average of all the 12 years of data, and the shaded area shows the total spread of all the data. Data from 1992 are shown as the black circles. A large number of "record" low values of total ozone were observed in 1992.

1991, 10 balloon sondes were flown during July and 39 lidar measurements were made during the same time period. All but one of the balloon sondes used in the climatology were flown after the 10th of July, which overlaps well with the GSFC lidar data in 1992, which was all recorded after the 12th. The lidar climatology is made up of all the measurements made during July, prior to 1991. The OHP lidar climatological profile extends from $20 \mathrm{~km}$ up to approximately $48 \mathrm{~km}$. Figure 2 shows a plot of the GSFC lidar data recorded in 1992 along with the balloon and OHP lidar climatological profiles. There were, unfortunately, too few sondes flown at OHP during August to construct a satisfactory climatological profile. There is an obvious difference between the July, 1992 lidar data and the climatology, particularly between 10 and approximately 28 $\mathrm{km}$. Because the OHP lidar climatology only extends down to $20 \mathrm{~km}$, it therefore misses a large portion of the ozone reduction noted when using the balloonsonde climatology, but over the range that the two overlap there is good agreement. The difference through most of this range is substantially larger than the standard deviations of the respective averages. This significant reduction in ozone is thus born out in the comparison of the 1992 lidar data with two independently measured climatological profiles. In this study we have not included any July, 1992 OHP lidar data because of the difficulties involved in trying to extract ozone information from a purely elastic scattered return, when there is a heavy aerosol loading.

If the combined lidar/sonde profile is integrated and the US Standard Atmosphere is used above $50 \mathrm{~km}$, the total column ozone amounts to 284 Dobson Units (DU), for the July, 1992 average profile, whereas the climatological profile integrates to $332 \mathrm{DU}$, a difference of $48 \mathrm{DU}$ corresponding to $14 \%$ less total column ozone in 1992.

The 1992 July and August TOMS data for the nearest grid point to OHP are plotted in Figure 3, against the 12 year average for the same months at the same grid point. The shaded area on the figure corresponds to the range of values recorded over the 12 years. The 1992 ozone levels are significantly lower than the average, and after about the 12th of July (day 195), most of the TOMS values are lower than the lowest values recorded in the previous 12 years. As mentioned above, all of the GSFC data were obtained after the 12th. The average of the TOMS data in 1992 for those days on which lidar data were obtained is $308 \pm 9 \mathrm{DU}$. The decrease in the total ozone from the TOMS July average is

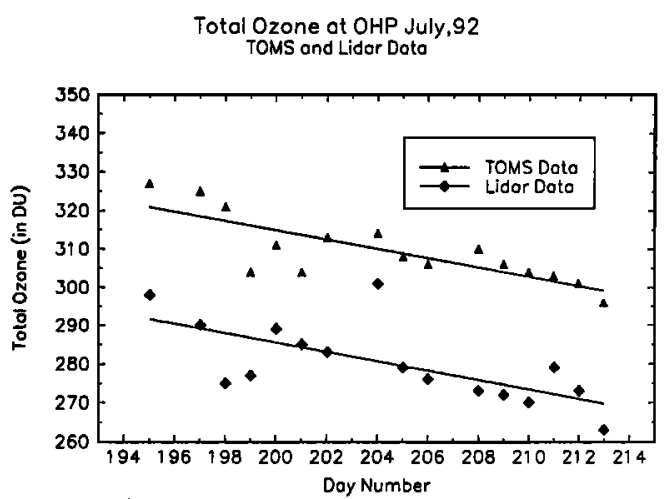

Mgare 4. A plot of the total ozone measured from the TOMS instrument during July, 1992, and of the total ozone from the lidar measurements on the same days. There is an offset which is discussed in the text, but the slopes of the lines are in good agreement.

approximately $27 \mathrm{DU}$, which amounts to an ozone reduction of nearly $10 \%$. The climatological profile integrated column of $332 \mathrm{DU}$ agrees quite well with the 12 year TOMS average for July, but the 1992 lidar data is somewhat lower than the July, 1992 TOMS measurements. We have plotted the TOMS measurements and the total ozone integrated from the lidar data in Figure 4. Each set of data has been fit to a straight

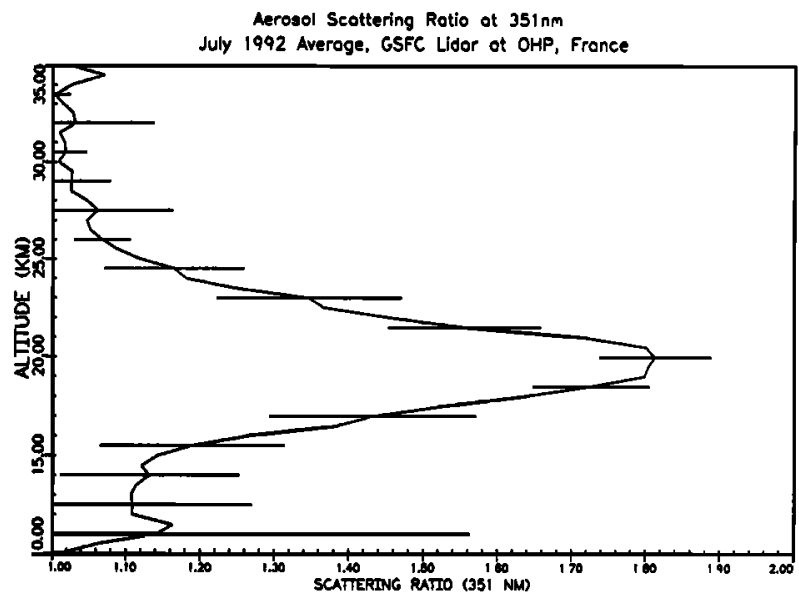

Figure 5a. A plot of the Aerosol Scattering Ratio which shows the vertical distribution of volcanic aerosols during July, 1992, above OHP. This is an average of the 14 nights in which lidar data was recorded.

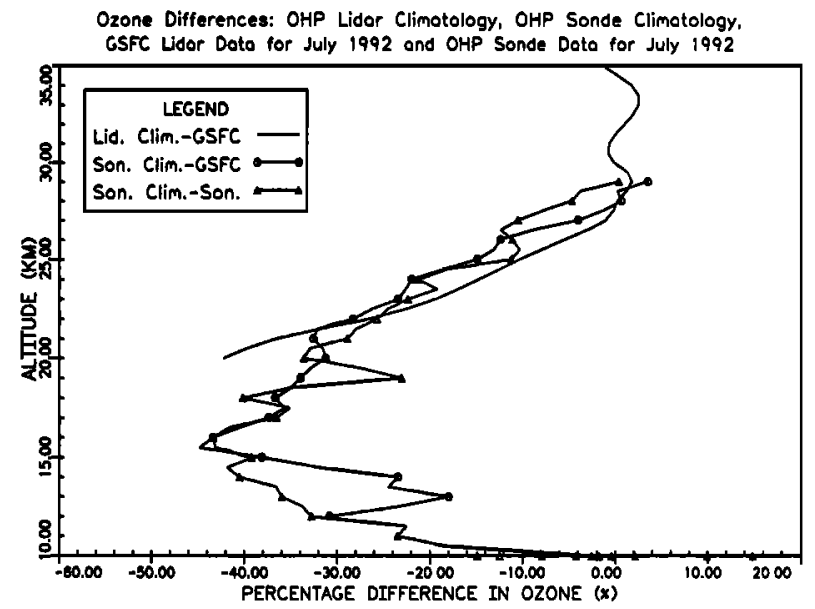

Figure $5 \mathrm{~b}$. The difference plot between the climatological profiles and the average of the fourteen July, 1992, lidar ozone profiles. The peak of the reduction in ozone is slightly lower than the peak of the aerosol layer, but it can be seen that the change in ozone occurs in the region of the aerosol cloud. 
line. The slopes of these lines are identical within the uncertainties of the fit, but there is an obvious bias between the data sets with the lidar data being lower than the TOMS. The lidar data compared to the sonde climatology shows a reduction in total ozone of about $14 \%$, while the TOMS July ' 92 data (taken on the days that the lidar made measurements) shows a reduction of about $10 \%$. This $4 \%$ difference between the lidar/sonde data and the TOMS data is within the estimate of error due to residual non-linearities in the Raman channels of the lidar. Another potential source of error is the extrapolation of ozone from the top of the lidar profile, although we would expect this to be small.

Several caveats must be applied to these data. Firstly, the TOMS grid point is not directly over OHP, and the data point encompasses a much larger area than either the balloon sondes or the lidar profiles. Most important is the fact that there are only ten balloon soundings in the climatology which were flown over the 6 years before the eruption of Mt. Pinatubo. The balloon sondes are generally considered to be accurate to within $\pm 10 \%$ which is borne out in Figure $1 \mathrm{~b}$. The discrepancy of $21 \mathrm{DU}$ between the lidar/balloon data and the TOMS data is larger than expected. The TOMS data is known to have a $4.5 \%$ bias compared to the World Standard Dobson Instrument No. 83 (McPeters and Kohmyr, 1991), however thhis should not be a factor when the TOMS data is compared with the TOMS climatology.

The more significant point we wish to make is the overlap of the volcanic aerosol layer with the region of reduced ozone. Figure $5 \mathrm{a}$ is a plot of the Aerosol Backscatter Ratio, defined above, which is a measure of the scattering due to aerosols. Experimentally, the ratio is formed by normalizing the Raman scattered return at $382 \mathrm{~nm}$ to the elastically scattered return at $351 \mathrm{~nm}$, and dividing the normalized Raman return (corrected for the wavelength dependence of the Rayleigh and Raman scattering) into the elastic return. The two returns are normalized between 30 and $35 \mathrm{~km}$, where aerosol scattering is negligible. It can be seen that there is significant Mie scattering between 14 and $27 \mathrm{~km}$. The feature at $10-12 \mathrm{~km}$ is due to scattering from a layer of cirrus clouds that was often seen in this altitude range. The remainder of the enhanced aerosol scattering displays extinction to backscatter ratios which are consistent with volcanic aerosols. This aerosol layer corresponds directly with the ozone deficit measured during July, 1992. Figure $5 b$ is a difference plot displaying the percent difference between the climatological profiles and the average GSFC lidar profile measured over OHP during the latter half of July, 1992.The lidar average is made up of all the lidar profiles recorded during July, 1992. Both traces show that the measured ozone depletion is correlated with the region of the atmosphere which has heavy aerosol loading. The comparison of the lidar data with both climatologies indicates that there is a major reduction in ozone between 14 and $24 \mathrm{~km}$, which amounts to approximately $10 \%$ of the total column content of ozone.

There are several ways that the presence of aerosols can affect the concentration of ozone. There can be modification of the "normal" chemistry by the hydrolysis of $\mathrm{N}_{2} \mathrm{O}_{5}$ on the surface of the aerosol particles (evidence for this has been presented by Webster et al., 1994); a change in ozone transport caused by aerosol induced radiative heating; or from subsequent changes in photochemical production and loss processes because of aerosol heating (Gleason et al., 1993). Without additional chemical data, however, it is impossible to determine the exact mechanism for the observed reduction in ozone. Hofmann et al., (1994) have reported a similar finding over Wallops Island, Va and Boulder, Co during 92-93 and have linked the changes to heterogeneous chemistry.

In summary we have reported direct evidence of a large depletion of ozone in the same altitude regime which shows heavy aerosol loadings from the 1991 eruption of Mt. Pinatubo. At some altitudes the reduction of ozone approaches $40 \%$. The coincidence of the aerosol layer and the ozone loss strongly suggests that the mechanism of the depletion somehow involves the presence of the aerosols. The exact nature of the mechanism for the change in ozone, however remains uncertain.

Acknowledgements. The authors from GSFC would like to thank the staff at OHP for their assistance in making the deployment successful. This research was supported by the NASA Upper Atmosphere Research Program and by the UARS Correlative Measurements Program. Funding for travel expenses came in part from SPA-AFEAS, INC. The authors would also like to thank the members of the GSFC Ozone Processing Team for providing the TOMS data used in this paper.

\section{References}

Ansmann, A., M. Riebesell, U. Wandinger, C. Weitkamp, E. Voss, W. Lanmann, and W. Michaelis, "Combined Raman Elastic-Backscatter Lidar for Vertical Profiling of Moisture, Aerosol Extinction, Backscatter, and Lidar Ratio", Appl. Phys. B, 55, 18-28, 1992.

Ansmann, A. U. Wandinger, and C. Weitkamp, "One-Year Observations of Mt. Pinatubo Aerosol with an Advanced Raman Lidar over Germany at 53.5 N", Geophys. Res. Lett., 20, 711-714, 1993.

Chandra, S., "Changes in Stratospheric Ozone and Temperature Due to the Eruptions of Mt. Pinatubo", Geophys. Res. Lett., 20, 33-36, 1993.

Gleason, J.F., P.K. Bhartia, J.R. Herman, R. McPeters, P. Newman, R.S. Stolarski, L. Flynn, G. Labow, D. Larko, C. Seftor, C. Wellemeyer, W.D. Kohmyr, A.J. Miller, and W. Planet, "Record Low Global Ozone in 1992", Science, 260, 523-526, 1993.

Hofmann, D.J., et al., "Ozone loss in the lower stratosphere over the United States in 1992-1993: Evidence for heterogeneous chemistry on the Pinatubo aerosol", Geophys. Res. Lett., 21, 65-68, 1994.

McGee, T.J., M.R. Gross, R.A. Ferrare, W.S. Heaps, and U.N. Singh, "Raman Lidar measurements of stratospheric ozone in the presence of volcanic aerosols", Geophys. Res. Lett., 20, 955-958, 1993.

McGee, T.J., D. Whiteman, R. Ferrare, J.J. Butler and J. Burris, "STROZ LITE: Stratospheric Ozone Lidar Trailer Experiment", Opt. Eng., 30, 31-39, 1991.

McPeters, R.D., and W.D. Kohmyr, "Long-Term Changes in the Total Ozone Mapping Spectrometer Relative to World Primary Standard Dobson Spectrometer 83", J. Geophys. Res., 96, 2987-2993, 1991.

Schoeberl, M. R., P.K. Bhartig, E. Hilsenrath, and O. Torres, "Tropical Ozone Loss following the Eruption of Mt. Pinatubo", Geophys. Res. Lett., 20, 29-32, 1993.

Webster, C.R., et. al., "Balloon profiles of stratospheric $\mathrm{NO}_{2}$ and $\mathrm{HNO}_{3}$ for testing the heterogeneous hydrolysis of $\mathrm{N}_{2} \mathrm{O}_{5}$ on sulfate aerosols", Geophys. Res. Lett., 21, 53-58, 1994.

(Received: January 6, 1994; Revised: May 16, 1994; Accepted: July 27, 1994) 